\title{
La metamorfosis de Toledo en la pintura de El Greco ${ }^{1}$ The Metamorphosis of Toledo in El Greco's Painting
}

\author{
Palma Martínez-Burgos García*
}

\begin{abstract}
RESUMEN
En el presente artículo se abordan los distintos enfoques con los que El Greco interpreta el paisaje de Toledo. Hábil en el uso de la escenografía, tal y como la había aprendido en su periplo veneciano y romano, sabe usar convenientemente los hitos arquitectónicos de Toledo para enmarcar sus composiciones religiosas. De este modo y bajo sus pinceles, Toledo se metamorfosea en Jerusalén, en Troya, en Egipto, en Tours o en las tierras toscanas que acompañan algunas de sus composiciones. Fragmentado o envuelto en el enigma, el perfil de Toledo responde al capricho de la clientela más culta, habituada al uso de la Historia y de la Antigüedad.
\end{abstract}

\section{PALABRAS CLAVE}

Metamorfosis, paisaje, escenografía, arquitectura,mitología, ficción y realidad.

\begin{abstract}
This article describes the various approaches used by El Greco to interpret Toledo's landscape. Skilled in the use of scenery, which he had learned in his trips to Venice and Rome, he knows how to use Toledo's architectural landmarks to frame his religious compositions. In this manner, and using his paintbrushes, Toledo metamorphoses into Jerusalem, Troy, Egypt, Tours, or the lands of Tuscany present in some of his works. Fragmented or shrouded in mystery, the profile of Toledo responds to the whims of the most cultured clientele, accustomed to the use of history and antiquity.
\end{abstract}

\section{KEY WORDS}

Metamorphosis, Toledo's landscape, scenograpy, architectture, mitology, fictions and realty.

\footnotetext{
* Profesora titular de Historia del Arte. Facultad de Humanidades de Toledo. UCLM.

1 Este artículo fue presentado parcialmente como ponencia en las Jornadas Los espacios sagrados en la ciudad de Toledo y su entorno, Toledo 2004, y se inscribe dentro del Proyecto de Investigación I+D BS02001-0947
} 
En el periplo vital descrito por El Greco están presentes algunas de las ciudades más bellas del Mediterráneo y, también, algunas de las más legendarias. Creta, Venecia y Roma han forjado los sueños de los habitantes del viejo continente y durante siglos, han sido permanente foco de atracción en el imaginario común. En ellas, El Greco llevó a cabo su formación como persona y como pintor. Nacido en Creta en 1546, sus primeros años se desenvuelven en un ambiente de un bilingüismo muy particular en el que se mezclaba lo oriental con lo occidental. Que se sepa, él nunca fue un «madonneri» en el sentido literal de la palabra, pero frecuentó los talleres más florecientes de la isla en los que si se cultivaba este estilo, y se familiarizó en el manejo de los grabados a través de los que se acercaba al arte del Renacimiento y al Manierismo contemporáneo.

Como autodidacta debió tener acceso a textos clásicos que enseguida le infundieron la idea del arte y del artista que conoce la cultura clásica, que proclama orgulloso su manejo y que ya no abandonará jamás. En cambio, los rasgos estilísticos de su temprana producción cretense vivibles en la Dormición de Ermoupolis apuntan hacia una factura ligada a los sistemas tradicionales de la pintura bizantina pero renovada. Como tal, no hay perspectiva ni tratamiento espacial, si bien la construcción arquitectónica sugiere una ambientación espacial, aunque muy rudimentaria ${ }^{2}$.

Después, su llegada a Venecia despierta en el joven cretense todas sus ansias por convertirse en pintor occidental. En los años de 1567 y 1570, la ciudad vive momentos de esplendor. Ajena a los problemas del Concilio de Trento y, por ende, ajena a la presión de la Inquisición, sus pintores tienen un punto en común; el tratamiento del color como valor plástico y constructivo, en menosprecio del «disegno", defendido por los florentinos y romanos. Esta será la primera de las lecciones que Doménikos aprende para ser el artista occidental que anhela. Tiziano, Tintoretto, los Bassano, preferentemente, van a ser quienes le abran el camino sobre el que explorar los valores cromáticos y tactiles del color. También intuye algo que no olvidará, la dignidad del Arte, como disciplina y filosofía, como método de aprehender y captar la naturaleza circundante, como vía de conocimiento. Empieza a perfilarse el artista filósofo que arraigará con fuerza durante su estancia en Roma y que acompañará a su fama, allá donde vaya ${ }^{3}$. De modo que, durante los tres años que permanece en Venecia, puede afirmarse que El Greco comienza a ser ese pintor que «piensa con los pinceles» y que se afianzará con fuerza en el ambiente culto y elitista que le rodeó en $\mathrm{Roma}^{4}$.

${ }^{2}$ Los años cretenses de Theotokopoulos han sido estudiados preferentemente por CoNSTANTOUDAKISKITROMILIDES y PANAGIOTAKIS quienes han buceado en los archivos cretenses y venecianos.

${ }^{3}$ F. MARIAS, El Greco, Madrid, Nerea, 1997. Es el autor que más ha subrayado el perfil filosófico del pintor frente a otras interpretaciones.

${ }^{4}$ Parece que en el círculo de Fulvio Orsini también coincide con Benito Arias Montano, humanista y bibliotecario de Felipe II en El Escorial que durante la estancia de El Greco en Roma, de 1570 a 1577, 


\section{EL DESCUBRIMIENTO DE LA ESCENOGRAFÍA: EL LOCUS GREQUIANO}

Su producción italiana asombra por la capacidad de aprendizaje y asimilación que Doménikos desarrolla en un periodo muy breve de tiempo. Prácticamente en diez años escasos, repartidos entre los que pasa en Venecia y los siete que transcurre en Roma, entre 1570 y 1577. En ese aprendizaje, quizás y al margen de la indiscutible vocación de El Greco, los grabados jugaron un papel importante como instrumento auxiliar y como medio de inspiración. Los maneja cada vez con mayor libertad y lo que a priori pudieran parecer «prestamos» literales, acaban convirtiéndose en soluciones originales y llenas de ímpetu ${ }^{5}$. También los viajes por Padua, Mantua y Verona le descubren el arte de Corregio y el de Parmigianino del que admira la figura "serpentinata», la más bella para resolver el cuerpo humano. Pero, además, la producción italiana de El Greco revela el dominio de la ciencia de la escenografía, dominio resuelto especialmente en las obras firmadas en Roma. En ellas muestra su admiración más rendida hacia Palladio, el gran arquitecto veneciano y hacia Serlio, de quien toma algunas citas para sus fondos arquitectónicos.

En sus pinturas hay dos tipos de escenarios que, por otra parte, eran los habituales a la hora de escenificar las historias. Los paisajes y las arquitecturas. En la etapa veneciana predominan las composiciones situadas en paisajes muy del gusto de la pintura véneta. No comportan ninguna dificultad a la hora de recrear el ambiente apropiado para la historia sagrada. Así, las tempranas composiciones con la Estigmatización de san Francisco o la de la Huida a Egipto revelan un interés por el paisaje que va más allá del recurso compositivo. Pero es evidente que en la concepción grequiana intervienen ya otros intereses. El prioritario fue abandonar la tradición bizantina en la que la tercera dimensión era menospreciada. Así, uno de los paisajes más espectaculares del pintor y en el que se advierten ciertos rasgos expresionistas es el enigmático Monte Sinaí del Museo de Creta (Fig. 1). En él se revela la mano de un pintor todavía bizantino y arcaizante. Aunque la primera composición acerca del Monte Sinaí es la que introduce en la tabla central del Tríptico de Módena, ésta, ya como pieza individual, fue pintada en Roma por encargo del bibliotecario del cardenal Alejandro Farnesio, Fulvio Orsini, quien gustaba de mantener contacto con las corrientes espirituales sinaíticas. El Monte Sinaí era uno de los lugares sagrados con más resonancias simbólicas y religiosas, tanto para los cris-

realiza dos viajes a la ciudad, por lo que parece razonable suponer un encuentro entre ambos personajes en el que se iría definiendo el viaje a España. En este panorama incide J. Alvarez LoPERA. EL Greco. La obra esencial, Madrid, Sílex, 1993. También y de forma más reciente el artículo de J. RoGELIO BuENDÍA. «El Greco: encuentros en Roma y su proyección en Toledo» en El Greco. The first twenty years in Spain, Rethymno, 2005, pp. 13-23.

5 La decisiva influencia que los grabados ejercieron en la formación de Domenikos ha sido estudiada en AA.VV. El Greco in Italy and italian art, University of Creta, Rethymno, 1999. Concretamente por F. MARIAS en «El Greco y los artistas de Italia: Venecia (1567-1570)», pp. 47-66. 


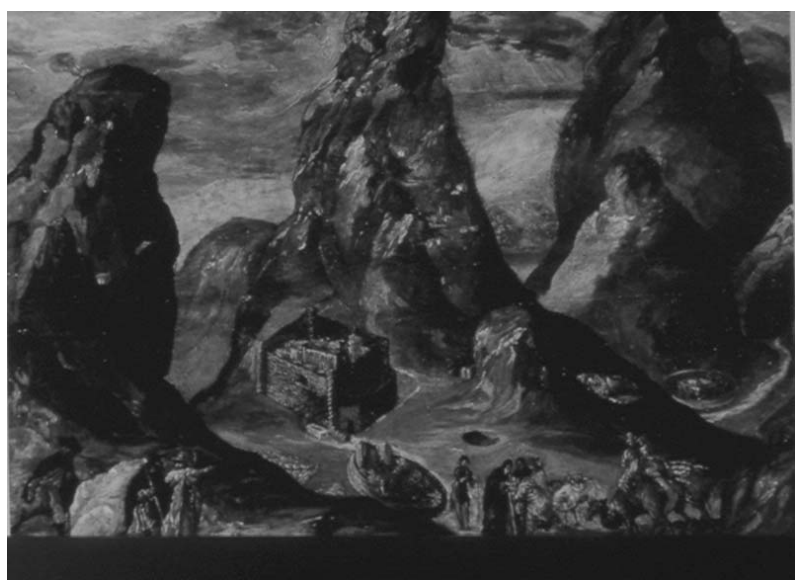

Fig. 1. Vista del Monte Sinaí. Creta. Museo de Heraklion.

tianos como para los judíos. Estaba formado por tres colinas; la central conocida como monte Horeb es donde tiene lugar la entrega de las tablas de la Ley a Moisés. También es el enclave en el que se levanta el monasterio a Santa Catalina, centro de peregrinación y lugar sagrado por antonomasia en la órbita bizantina.

En el paisaje pintado por El Greco se recogen cada uno de estos aspectos y a pesar de ello, el espectador es consciente de que no se halla ante una interpretación topográfica. Todo lo contrario, más bien se trata de un retrato espiritual en el que da una concepción tan personal como arcaica y extraña. Sobre todo si lo comparamos con los grabados que circulaban por Europa, realizados por G. B. Fontana e inspirados en las Escenas de la vida de San Roque, pintadas por Tiziano ${ }^{6}$. Frente a esos modelos, El Greco emplea una paleta umbría y rocosa y desarrolla un paisaje caracterizado por la intensidad emocional y el fuerte claroscuro. En la parte inferior, unas figuras, casi en miniatura, se perfilan como peregrinos envueltos en una atmósfera irreal, crepuscular y profundamente espiritual. La misma que volverá a presidir la impresionante Vista de Toledo que pintará muchos años después.

Amén del paisaje, El Greco indaga en otros registros y durante sus años de estancia en Roma aborda en varias versiones dos temas sobre los que trabaja incansablemente, la Curación del ciego y la Expulsión de los mercaderes. Ambas son dos historias de fuerte carga contrarreformista ${ }^{7}$. Realiza hasta tres versiones

6 Confrontar lo referido en la nota anterior respecto a la influencia del grabado en el arte del cretense.

7 El primero viene a significar la llegada de la luz espiritual que trae la revelación divina, frente a la ceguera de los que no quieren ver, en alusión a los protestantes. También se ha dicho que el interés de $\mathrm{El}$ Greco por este pasaje evangélico responde a otros factores, pues se ha interpretado como una alusión a su propia conversión a la fe católica, abandonando el credo ortodoxo L. PUPPI, «El Greco en Italia y el arte italiano» en J. Álvarez LOPERA, (Ed.) El Greco. Identidad y transformación, Skira, Madrid, 1999, pp. 97-118. 
con la curación milagrosa del ciego y a través de ellas, se puede reconstruir el arduo aprendizaje emprendido por el cretense para dominar la escenografía, o ciencia del espacio, y la perspectiva arquitectónica que tanto impacto le provocó. En la última de las versiones, la de la Galería Nazionale de Parma, la más madura, se advierte el calado del ambiente romano en el joven cretense. Se advierte, especialmente, el culto a la Antigüedad y el cúmulo de citas clásicas con las que envuelve el relato, donde podemos identificar el pronaos del Panteón romano, los ecos del Arco de Constantino o el «tepidarium» de las Termas de Diocleciano recreado en el bello pórtico del fondo que se proyecta nítidamente contra el cielo. De ahora en adelante y como narrador de historias, El Greco va a introducir los escenarios que tiene a mano. No es una invención propia, puesto que la pintura italiana viene haciéndolo y, en especial, los venecianos. De todos modos, la moda era absolutamente nueva en España donde la introduce el pintor. Al igual que hará con los personajes de su entorno, convirtiéndoles en testigos de sus composiciones, también el escenario se libera del yugo arqueologizante para resolverse en uno de los recursos de mayor belleza y libertad en el Arte, el de acudir al escenario urbano próximo e inmediato, en el que se juega entre la ficción y la realidad.

A priori no era fácil de aceptar ya que las pautas dadas por los moralistas después del Concilio de Trento no dejaban lugar a las dudas. En la pintura religiosa debía desterrarse todo aquello que no estuviera contrastado por las fuentes oficiales, y, en consecuencia, la historia debía ser construida partiendo de la fidelidad al tiempo y lugar en el que ocurrió. Los anacronismos, habituales en los métodos pictóricos del Renacimiento, fueron desaconsejados, en ocasiones censurados. Pero nadie más ajeno a estas imposiciones que el espíritu libre y rebelde con el que El Greco desembarcó en España. Cuando lo hace es ya un hombre formado y maduro, conocedor a fondo de la gran pintura italiana y poseedor de un bagaje intelectual poco habitual en la península.

El pleito con la catedral y el rechazo de Felipe II confirman lo esquiva que le estaba siendo la Fama. De modo que al no poder contar con cargos ni pensiones, El Greco entró en el mercado libre ejerciendo una competencia justa y leal con el resto de los artistas instalados en la ciudad. También su estilo sufre un paulatino cambio que se irá acentuando con el tiempo ${ }^{8}$. Los ecos de italianismo tan evidentes de sus primeras obras en Toledo empiezan a dejar paso a un lenguaje original y desconocido en la ciudad. Un lenguaje que se alimenta de distorsiones, de luces centelleantes y de un progresivo abandono de la realidad para dar cabida a una abstracción intelectual que le lleva a concebir un canon humano entre las nueve y

\footnotetext{
8 Ver P. Martínez-Burgos García, «El Greco y Toledo: los cuadros de devoción en el marco espiritual de la Contrarreforma», Boletín de Arte, n. ${ }^{\circ} 24,(2003)$, pp. 13-34. En el artículo se recogen los parámetros espirituales y religiosos que marcaron la producción devocional de El Greco. Una visión más generalizada en P. Martínez-Burgos García. El Greco. Un pintor humanista, Madrid, Libsa, 2004.
} 
once cabezas, con lo que crea un prototipo fiel al Manierismo más exacerbado. Esta búsqueda es lo que le concede Toledo, la libertad para crear y desarrollar un estilo que se articula al margen de reglas y modas convencionales.

\section{EL PAISAJE DE TOLEDO, FRAGMENTACIÓN Y CONTEMPORANEIDAD}

Una de esas libertades fue la que se tomó a la hora de recrear escenográficamente sus temas religiosos. Es sorprendente ver que al pisar suelo español El Greco abandona la difícil disciplina de la escenografía arquitectónica que tanto le había costado dominar y que caracteriza su etapa romana. Nunca más vuelve a utilizarla; en cambio, despliega una sorprendente visión del paisaje como fondo de sus composiciones. A partir de 1587 y de forma casi exclusiva, el único paisaje que interesa a El Greco es Toledo, si bien el tratamiento pictórico es tan subjetivo como intelectual. Al margen de la primera impresión, el Toledo que se cuela por sus fondos pictóricos no es real y eso a pesar de que se puedan reconocer los hitos arquitectónicos que definen la «línea del cielo» de la ciudad castellana. Es decir, la silueta del alcázar, el perfil de la torre de la catedral, los puentes de Alcántara y de San Martín, el castillo de San Servando o los paños de las murallas. Todos ellos se reconocen y se leen sin dificultad, pero su inserción en el paisaje es completamente artificial porque responde a una labor previa de fragmentación, de modo que el paisaje unitario, la naturaleza completa que ofrece Toledo, se ve sometida a una «descomposición» calculada y seleccionada. Así es como aparece un Toledo desestructurado, reconocible en las composiciones de la Inmaculada Concepción con San Juan Evangelista y en la Inmaculada de la capilla Oballe, ambas en el Museo de Santa Cruz, o en las numerosas versiones que hace del Bautismo de Cristo. En ellas, mediante un proceso de abstracción que le acerca a sus orígenes bizantinos, El Greco convierte los hitos urbanísticos en símbolos de la letanía mariana. Bajo un cielo nocturno podemos identificar la «porta coeli» que sirve de frontispicio a la «turris David» concebida como un tholos clásico. A la derecha el cedro del Líbano, el ciprés de Hermón, la palmera de Engeadí (tomados del Ecclesiastés 24, 13-14) y la muralla que actúa como "hortus conclussus» tomado del Cantar de los Cantares (4:15). Son elementos que podemos contemplar en la composición de la Inmaculada Concepción con San Juan Evangelista (Fig. 2), en la que de forma magistral El Greco une dos capítulos hasta ahora separados; la visión apocalíptica del triunfo sobre el pecado con la que se representaba la Inmaculada Concepción y la más tradicional en la iconografía de Occidente, la Asunción de María. La fusión hecha por el Greco fue contundente y efectiva porque solventaba el problema de la defensa de la Inmaculada Concepción sin plantear el problema del dogma. La acogida de esta novedad iconográfica debió contar con los para- 


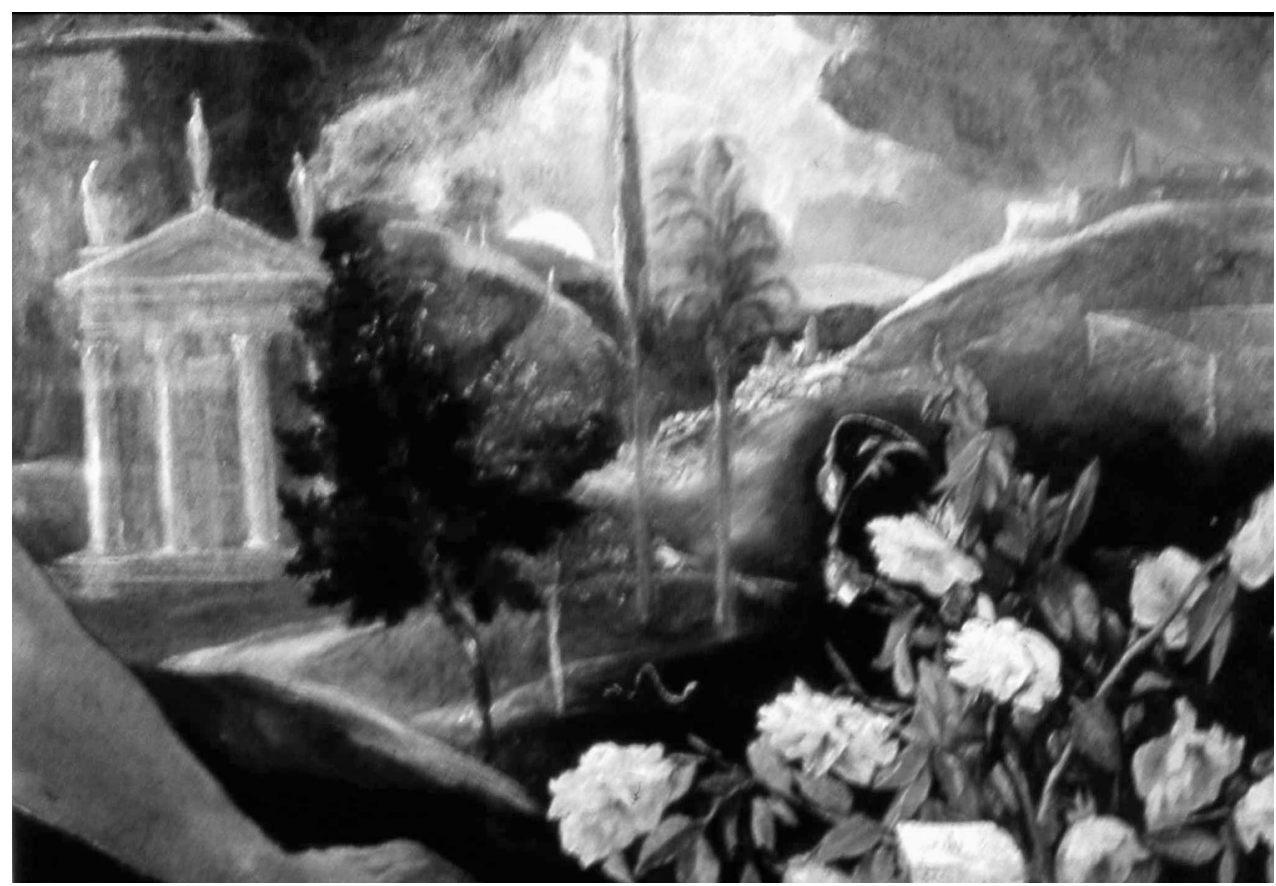

Fig. 2. Inmaculada con San Juan Evangelista. (Detalle) Toledo, Museo de Santa Cruz.

bienes de la clientela, si bien se ha dicho que esta fórmula pudo estar inspirada en los escritos del teólogo toledano Alonso de Villegas, autor de la Flos sanctorum más erudita de la época. Publicada entre 1578 y 1589, supuso una de las apuestas historiográficas más interesantes del momento en la que se recoge el espíritu de la Contrarreforma ${ }^{9}$. Es posible que se conocieran y que frecuentaran ambientes parecidos. Aún así, el éxito de la fórmula le permite volver a plantearla en la Inmaculada Concepción que pinta para la capilla Oballe entre 1607 y 1613. Entre ambas imágenes hay una distancia de veinte años que se evidencia por una transformación mas «emocional» de las figuras pero el esquema se mantiene, lo que nos permite reconocer los mismos símbolos de la letanía junto al ramo de rosas y azucenas entre las que se cuela la firma del pintor.

La idea de esparcir los elementos bíblicos por el paisaje natural era tan obvia que parece imposible que no se le ocurriera antes a nadie, pero así fue. El Greco

9 En una idea apuntada por el historiador J. BROWN en «La visión de San Juan de la Inmaculada Concepción de El Greco» en AA.VV. La Inmaculada de El Greco. Toledo, 1997. Se trata de un estudio publicado con motivo de la restauración del cuadro y que permitió un análisis completo de su conservación. 
es el primero en aprovechar el potencial paisajístico de Toledo que, al insertar los símbolos o jeroglíficos, adquiere una dimensión supra irreal convirtiéndose en la visión apocalíptica de San Juan. A su vez, el puente de Alcántara, el castillo de San Servando o la torre de la catedral sirven de citas bíblicas con las que construir el esqueleto del paisaje de la ciudad, que de forma casi idéntica se reproducen en composiciones como la Vista de Toledo. Nadie antes había hecho nada similar en pintura, sin embargo es posible hallar un precedente literario para la fantasía grequiana. La Crónica de San Ildefonso habla de la «casa de Dios» y de la «puerta del cielo» para referirse a Toledo y su catedral y, en pleno Siglo de Oro, Lope de Vega incluye los mismos términos en la obra que dedica al santo toledano bajo el título El capellán de la Virgen que sin duda pudo conocer Domenikos ${ }^{10}$.

Pero no siempre El Greco descompone el paisaje de Toledo, es más, la mayoría de las ocasiones lo toma de forma íntegra para enmarcar espacialmente sus composiciones. En este sentido, su mirada siempre tiene un enclave fijo. Diríase que se sitúa en el camino de Madrid y desde allí siluetea el perfil imaginario de la ciudad compuesto por la catedral, el Alcázar, la vertiente de la muralla en su desnivel hacia el Alcázar y el puente de Alcántara al otro lado, todo ello en medio de una vegetación que recrea la exuberante huerta que cierne el Tajo. Estos son los componentes de la impresionante Vista de Toledo (Fig. 3). Representa un paisaje sometido a una luz tan irreal como tétrica. Bajo unos efectos relampagueantes en blanco y toques acerados de azul, escoge la silueta más habitual ya descrita con la remontada hacia el castillo de San Servando. La verosimilitud topográfica, sin embargo, esta distorsionada en aras de una mayor expresividad. Algunos de los hitos que marcan la línea del cielo de Toledo, como la torre de la catedral, se han cambiado de lugar. Aparece a la izquierda cuando en realidad esta a la derecha y otros elementos, o ya no existen o son fruto de la invención del pintor. El resultado final es tan bello como sugerente siendo una de las composiciones que ha alimentado la visión expresionista que el siglo xx reclamó para el cretense. Sin duda, porque es una creación llena de misterio y con un gran componente subjetivista y emocional. En esencia es una imagen verídica como verídica es la curva del paisaje que describe, pero al estar magnificada y acentuados los desniveles del terreno cobra vida por sí misma. Lo mismo ocurre con la naturaleza árida y pedregosa de la tierra castellana que ha quedado transfigurada bajo una paleta de verdes y azules relampagueantes. En conjunto, son recursos que se habían puesto de manifiesto en la Vista del Monte Sinaí lo que hace que entre las dos composiciones, a pesar del tiempo que les separa, haya un estrecho lazo.

10 LoPE DE VeGA, El capellán de la Virgen, en Obras selectas, Edición de Federico Carlos Sainz de Robles, Aguilar, Méjico, 1991, tomo III. Para más información ver el sugerente estudio de F. MARTíNEZ GIL, «De Civitas regia a Civitas Dei. El imaginario histórico de Toledo durante los siglos XVI y XVII» en Los espacios sagrados en la ciudad de Toledo y su entorno (en prensa). 


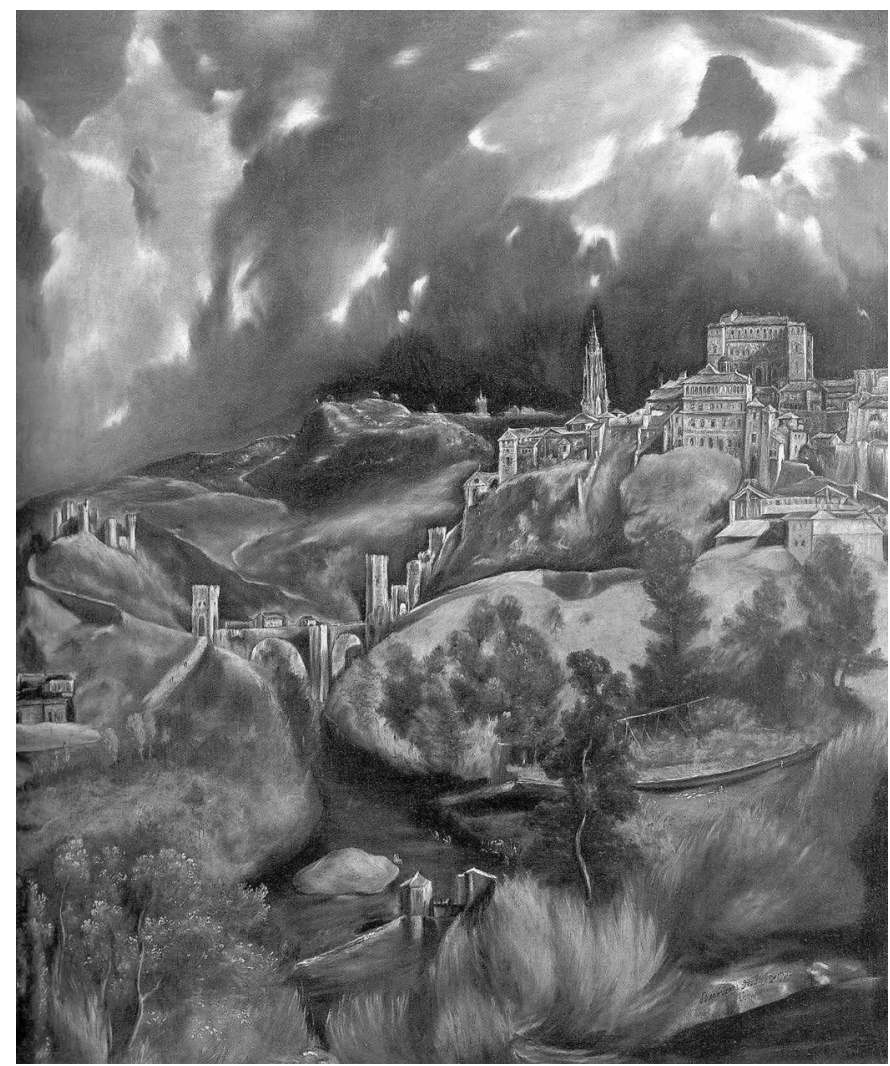

Fig. 3. Vista de Toledo. Nueva York, Metropolitan Museum of Art.

Como tantas veces volverá a ocurrir en la obra del Greco, Toledo se transforma prestándose a interpretaciones no siempre coincidentes. Desde aquellas que buscan la identidad entre el pintor y la ciudad, a las que adivinan el contenido místico que el cretense vuelca en ella. Pero también se han barajado otros argumentos de carácter emblemático, literario, artístico y simbólico, aunque ninguno de ellos sea suficiente para explicar los dos factores claves de este paisaje, la distorsión de la realidad y la atmósfera de alucinación que le impregna ${ }^{11}$.

11 En efecto, WETHEY apuntó que las particularidades del paisaje pintado por Doménikos respondían al deseo de insertarlo en las corrientes artísticas que empezaban a volcarse sobre este género, estableciendo una hipotética conexión con el paisaje flamenco de Brueghel. Por su parte BRown y KAGAN señalan la corriente emblemática como sustrato ideológico que explica la interpretación de EI Greco, mientras que la historiografía decimonónica lo ha utilizado como base para la exaltación mística y «nacional» del alma castellana que invade al pintor. Muchas de estas reflexiones han sido desarrolladas por J. Álvarez Lopera, op.cit. pp. 228-230. 
Con anterioridad a la Vista de Toledo, El Greco ya había ensayado la inclusión de la ciudad en sus composiciones religiosas. En ellas es donde se pueden establecer los tópicos manejados y las metamorfosis que Toledo asume en su papel escenográfico. Entre los ensayos más tempranos se sitúan los paisajes que cuela en el pasaje de la Crucifixión. Se trata de uno de los temas más recurrentes en el catálogo del pintor aunque en realidad la mayoría de los lienzos que circulan por el mercado son obras de taller, siendo pocas las que se pueden considerar autógrafas. En cualquier caso, la composición de la escena responde a un patrón tipo en el que apenas caben variantes, si acaso, la inclusión de personajes acompañando la agonía. Su gran creación fue la modalidad de Cristo crucificado en solitario, lo que le permite disponer al pie de la cruz un simbólico paisaje en el que coloca los hitos arquitectónicos recurrentes, aunque siempre con un claro contenido sagrado. De esta variante existen dos bellos ejemplares como el de la colección Zuloaga o el de la Santander-Central-Hispano. Ambos responden a un esquema compositivo idéntico ya que en el centro destaca la gran altura de la cruz, lo que le permite disponer una línea de horizonte muy baja y jugar con amplios y atormentados cielos. En ella el cuerpo longilíneo de Cristo describe siempre una "serpentinata» típicamente manierista como también lo es el tratamiento de la luz que despide la anatomía sagrada. Esta vivo, sin muestras de dolor, salvo unas pequeñas gotas de sangre que caen por manos y pies, y dirige la mirada hacia lo alto, buscando la protección del Padre. Los tonos crepusculares que bañan los cielos ceden en el paisaje a una paleta más terrosa. En la versión de la colección Santander (Fig. 4) y en la del Museo Cincinati podemos identificar con claridad la apuesta realizada por el Greco. Aquí, tras la calavera de Adán se reconocen los elementos emblemáticos de la ciudad en una panorámica que le recorre de punta a punta incluyendo el puente de San Martín. Usados arbitrariamente estos elementos consiguen hacer de Toledo el escenario de la levítica Jerusalén. En otras versiones en vez de Toledo, El Greco se deja seducir por la fascinación indudable que El Escorial ejerció en su vida. Así, en el lienzo de la colección Zuloaga, al fondo y tras la arboleda se adivina la silueta del monasterio, la misma que podemos encontrar en la composición de San Juan Bautista, pintado hacia 1600 y con la que actualiza la escena evangélica.

Esta podría ser una de las razones del porqué El Greco acude a paisajes familiares en plena vigencia de la Contrarreforma, que exige fidelidad a la verdad histórica y huye de los anacronismos. Frente a un escenario ajeno y desconocido que deja indiferente al fiel, El Greco opta por «acercar» el motivo religioso en un proceso de «empatía», es decir de identificación. La proximidad y familiaridad del paisaje ayuda a convertir el mensaje evangélico en algo cercano y próximo, válido para los hombres de todos los tiempos, de tal manera que se 


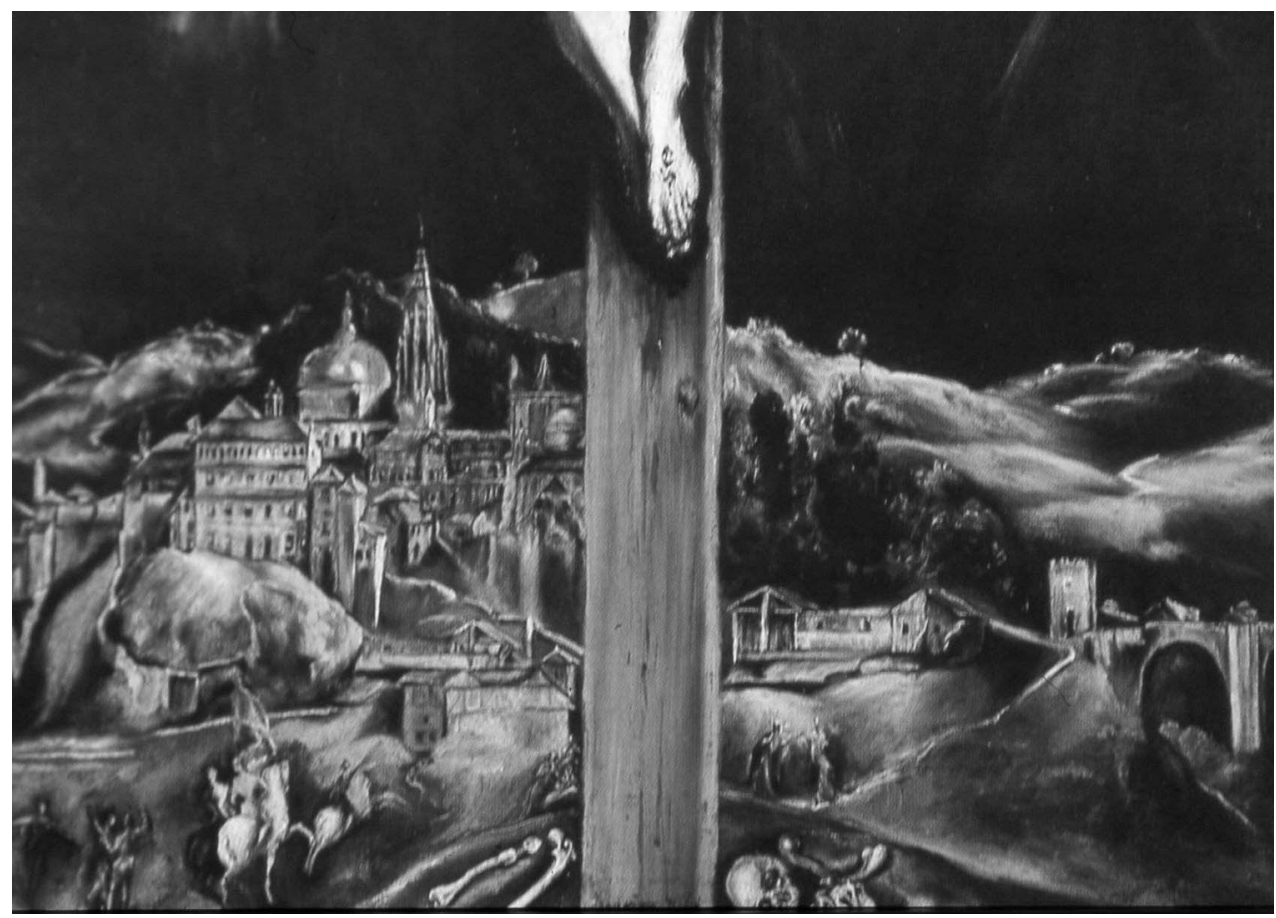

Fig. 4. Crucifixión. (Detalle). Madrid, colección Santander.

produce un fenómeno de «contemporaneidad» por el cual el fiel no se siente excluido $^{12}$. A juzgar por la demanda de la clientela y la ingente producción de las obras devocionales salidas del taller del cretense, se reconoce el éxito de la fórmula que mantiene también en los grandes encargos. Uno de ellos es el que contrata con el erudito D. Martín Ramírez de Zayas para la capilla de San José. Catedrático de Teología en la universidad de Santa Catalina, su fundación se destinaba a capilla panteón para él y sus padres. A manera de oratorio privado e íntimo, se pone bajo la advocación carmelita de San José. El contrato se firmaba en noviembre de 1597 y comprendía un ambicioso programa de tres retablos con sus consiguientes pinturas y esculturas. Menos los lienzos, todo fue rehecho en 1613, sufriendo la intervención de diferentes artistas a lo largo del XVII ${ }^{13}$.

12 Un proceso similar, aunque en otra esfera, era el que había desarrollado la pintura flamenca, al vestir a los personajes sagrados según la moda de la época y en entornos domésticos y urbanos que nada tenían que ver con la Palestina retratada por las Sagradas Escrituras.

${ }_{13}$ Quien mejor ha estudiado la dispersión de la obra grequiana, y especialmente este conjunto ha sido A. E. Perez SÁnCheZ. «Las series dispersas de El Greco» en J. Brown, op, cit. 


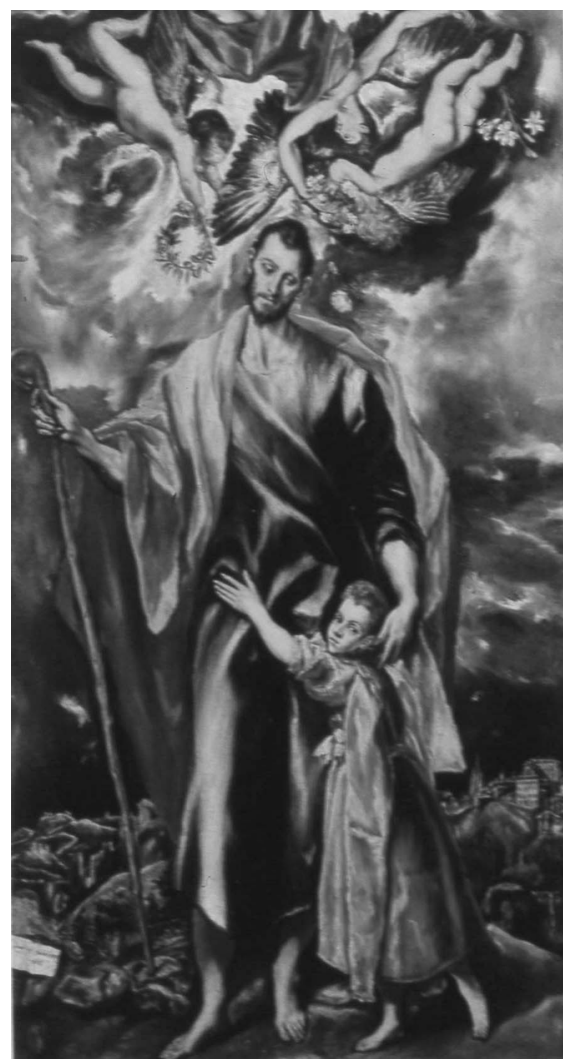

Fig. 5. San José con el Niño. Toledo, Catedral.

En el retablo mayor aparece San José con el Niño, una de las realizaciones más líricas del pintor (Fig. 5) ${ }^{14}$. Maneja un estilo cercano a la idealización y equilibrio clásicos comunes al arte italiano. En el centro y con la consabida desproporción grequiana, dispone a un San José con el que renueva la tradición medieval. El contexto social y espiritual del siglo xvı explica en parte la novedosa interpretación de El Greco. Se ha dicho que al concebirle como un joven fuerte y decidido Theotokopoulos vendría a reivindicar la falta de mano de obra provocada por la inminente expulsión de los moriscos, que dejó a la península sumida en la precariedad del trabajo y de los oficios Además, la imagen del santo coincide con una corriente de revitalización de su papel, hasta entonces bastante maltratado. El carmelita

${ }^{14}$ Es la versión que guarda la catedral de Toledo, también firmada pero de reducido tamaño, algo más de un metro de alto por medio de ancho. Podría estar pintada por las mismas fechas y da muestras del éxito que tuvo la versión propuesta por Doménikos. 
Jerónimo Gracián de la Madre de Dios publica en 1597 uno de los textos más ilustrativos de este fenómeno, el Sumario de las Excelencias del glorioso San José, esposo de la Virgen María. Esta concebido de frente y envuelto en un elegante cromatismo, sostiene con una mano el bastón mientras que con la otra cobija al Niño que le abraza tiernamente. Arriba un coro de ángeles, en vertiginoso movimiento y escorzos, juguetean con las guirnaldas de rosas y laurel, alusión simbólica a la sabiduría del fundador, D. Martín Ramírez de Zayas. En el fondo, en una línea de horizonte muy baja, dispone el paisaje de Toledo recurrente en sus composiciones religiosas. Puede que la escena tenga lugar durante la vuelta de la huida a Egipto, por lo que esta vez transforma libremente la visión de aquellas tierras lejanas en su cercana ciudad. Nuevamente se hallan presentes todos los elementos arquitectónicos recurrentes y tipificados. También están sus cielos, los que $\mathrm{El}$ Greco inmortalizó, amplios celajes, plomizos y acerados que ensombrecen la ternura de la imagen infantil, llenándola de malos presagios.

Para la misma capilla pinta el San Martín partiendo la capa que ocupaba el altar de la izquierda de la capilla y esta considerado como una de las obras de mayor calidad del cretense. Se trata de un homenaje explícito a la figura del fundador de la capilla, Martín Ramírez de Zayas y se ha dicho que en ella se evidencia el recuerdo de «los airosos cielos venecianos» en opinión de Xavier de Salas. En esta ocasión, la ciudad francesa de Tours, en la que tiene lugar el milagro, se convierte en Toledo, donde volvemos a identificar el puente de Alcántara en primer plano.

Un caso de manipulación narrativa similar es el que presenta en otra de sus creaciones finales y que al igual que las de la capilla de San José era un encargo completo. En esta ocasión para el colegio universitario de San Bernardino bajo advocación franciscana ${ }^{15}$. Para su creación El Greco parece seguir a Jacobo de la Vorágine y la Leyenda Dorada, donde se dan las pautas biográficas que permiten fijar su iconografía. La composición se ha solucionado a partir de un sutil juego de triángulos, en los que se inscribe tanto la figura como su cabeza. En cuanto al estilo se advierten varios rasgos que nos sitúan en la etapa final del cretense. Para empezar, la extraordinaria desproporción de su figura en la que El Greco dispone el canon próximo a las trece cabezas, con lo que resulta una imagen cercana a la de San José. En ambas, la proximidad al espectador y el horizonte tan bajo provocan una rotundidad imponente. Sin embargo, aquí la paleta de los colores se ha reducido de forma ostensible. Predominan los ocres y marrones, tanto que puede

${ }^{15}$ El contrato fue hecho por los universitarios Juan Bravo de Acuña y Luis de Beluga y en el se le pedía la ejecución arquitectónica del retablo, concebido dentro de las pautas de un latente clasicismo por parte de El Greco, con capitel jónico-dórico, friso curvo y frontón triangular, y el enorme lienzo con el titular de la institución. El conjunto de retablo y lienzo estuvo disperso entre los años de 1846 hasta 1962, año en el que volvió a reconstruirse gracias a la fundación Vega-Inclán, fundadora de la Casa-Museo de El Greco. Ver F. Marías y A. Bustamante, Las ideas artísticas de El Greco, Cátedra, Madrid, 1981. 
llegar a parecer una composición casi monócroma. La nota discordante, frente a esta gama, la dan los celajes tan amplios con los que arropa el paisaje, en el que nuevamente se vuelve a adivinar la imagen de Toledo y sus cigarrales, esta vez para recrear las tierras italianas de Siena, Urbino y Ferrara entre las que discurre la vida del santo (Fig. 6).

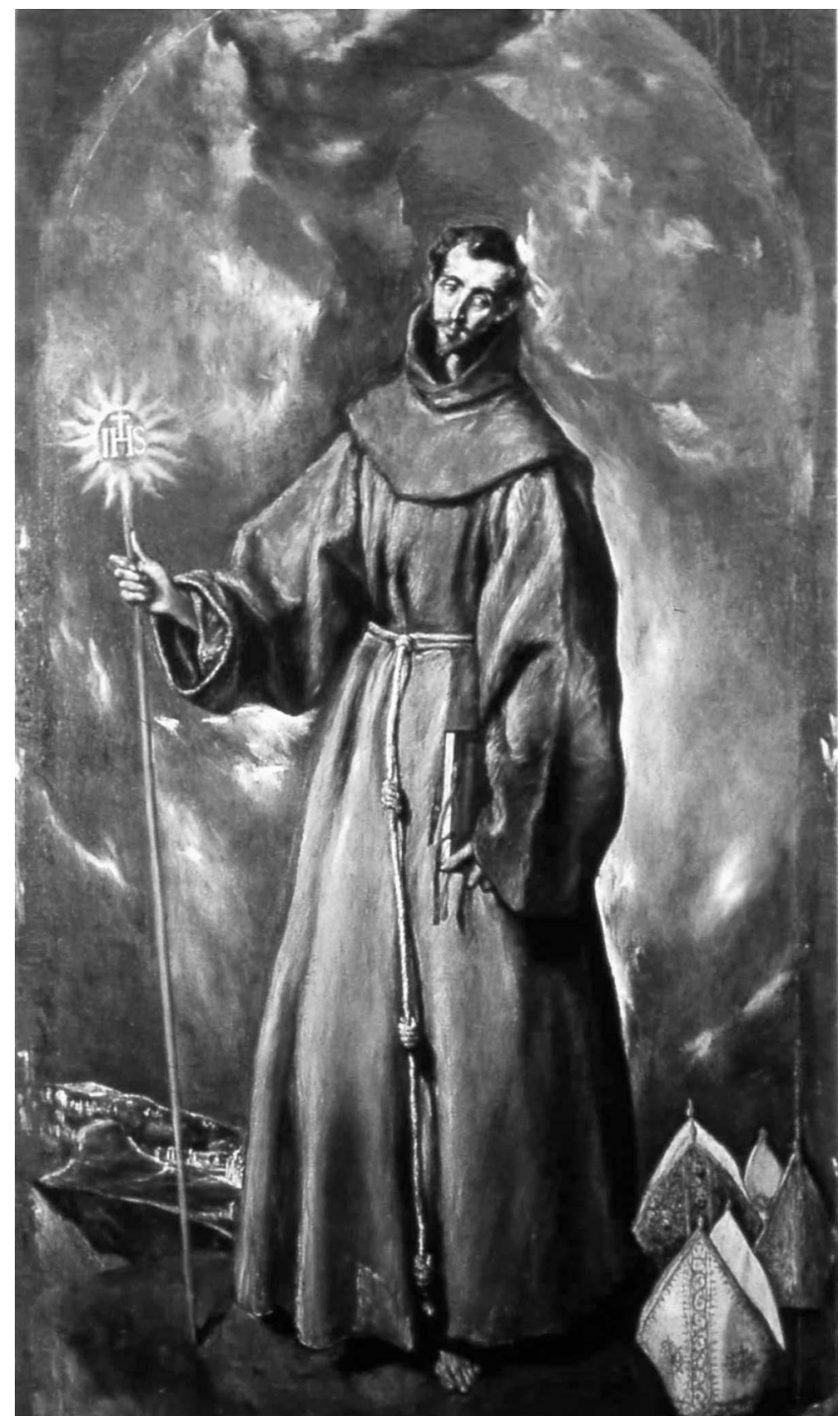

Fig. 6. San Bernardino. Toledo, Museo de El Greco.

(c) UNED. Espacio, Tiempo y Forma Serie VII, H. ${ }^{a}$ del Arte, t. 17, 2004 


\section{FICCIONES, ENIGMAS, REALIDADES}

Al final de su vida, El Greco vuelve a dar dos interpretaciones soberbias de la ciudad de Toledo como espacio sagrado por antonomasia. Una responde al género de la mitología, la otra a la pintura religiosa. Ambas fueron pintadas en las mismas fechas, 1608-1614. La primera es una verdadera excepción en el catálogo del cretense. Se trata del Laocoonte, única pintura mitológica que encontramos en su repertorio, lo que le hace aún más excepcional (Fig. 7). El Greco no siguió la fuente de Virgilio sino que demostró, una vez más, su bagaje cultural y acudió a textos menos conocidos como el de Arctinos de Mileto con lo que aporta una reflexión nueva y parcialmente conocida de la historia. Según este autor, junto al padre sólo muere uno de los hijos a manos de la serpiente que derriba al sacerdote mordiéndole en la cabeza, mientras que el otro todavía lucha denodadamente.

Al fondo, la imponente ciudad de Toledo, convertida en la Troya grequiana, y bajo un cielo pleno de presagios dramáticos, presencia el combate del sacerdote, a cuyo costado yace el hijo muerto, mientras advierte con pavor la serpiente a punto de morderle. En el extremo izquierdo, el otro vástago se debate entre la vida y la muerte, todavía de pie, describiendo una curvatura insólita. Y a la derecha, unas figuras contemplan ajenas el drama que se representa. A pesar de las imágenes que el Helenismo había legado y, a pesar de los grabados que circulaban por doquier difundiendo la tragedia de Laocoonte, la interpretación de El Greco es absolutamente original, si bien podemos reconocer algunos préstamos que toma de otras composiciones suyas. Tal y como ha sido señalado, el escorzo que describe el hijo ya muerto o la postura del sacerdote troyano están tomadas de las figuras de San Mauricio y la legión tebana y también de los soldados que testifican la Resurrección de Cristo. Sin embargo, nada hay en el cuadro que delate la mano cansada y vacilante del pintor, que sigue planteando enigmas al espectador. Al día de hoy no se ha dado con la clave que encierran los tres personajes que desde el ángulo derecho contemplan la escena. En torno a ellos permanece el misterio y se abren todas las interrogantes ¿Adán y Eva, Epimeteo y Pandora, Paris y Troya... ${ }^{16}$. Cualquier respuesta sería válida lo que abre múltiples posibilidades de lectura en el cuadro que, al final, podría convertirse en una versión cristianizada de la Antigüedad.

Cabría preguntarse por qué en los años finales aborda este tema y lo hace con tal fuerza y dinamismo. Es cierto que desde que se halló el grupo del Laocoonte,

\footnotetext{
16 Los tres rostros, hay uno que se vuelve al espectador aumentando la sensación tan enigmática, fueron descubiertos tras la limpieza efectuada en los años 1955-56 y desde entonces han hecho correr ríos de tinta. Algunas de las apuestas más interesantes son las de MofFIT, (1984) y las de SAXL, (1927-29).
} 


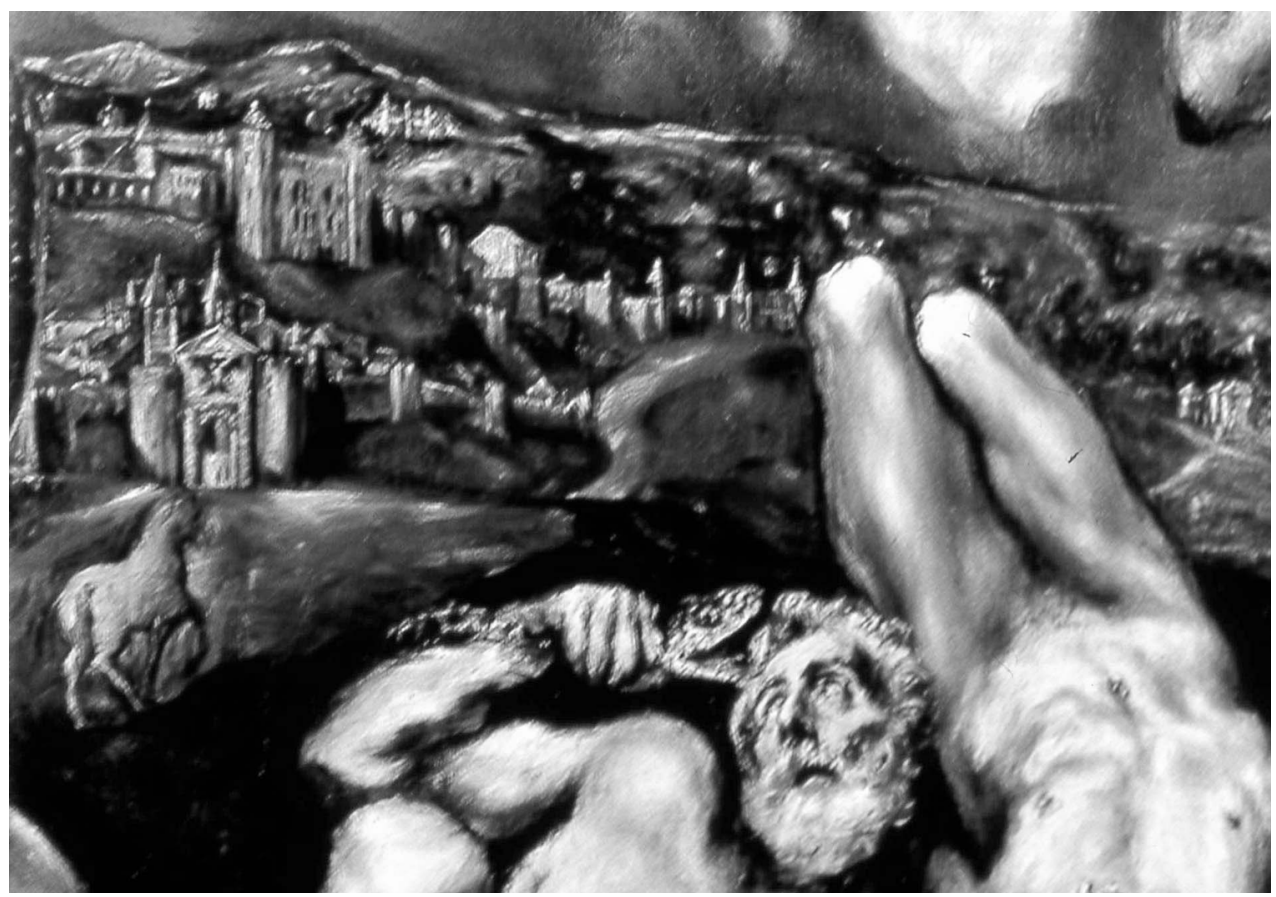

Fig. 7. Laocoonte (Detalle). Washington, Nacional Gallery of Art.

en 1506 no dejó de inspirar tanto a los humanistas como a los artistas del Renacimiento. Sin embargo, por parte de El Greco se ha querido ver un homenaje hacia el arzobispo de Toledo condenado por la Inquisición, Bartolomé de Carranza. Al igual que el sacerdote troyano, su prudencia y su voz profética acerca de los males que acechan no fueron oídas y se redujeron al silencio. Waterhouse primero y Davies después apuntaron la secuencia completa de esta hipótesis ${ }^{17}$. Pero como es habitual en Domenikos, la historia mitológica le permite desarrollar otros mensajes como el deseo de ennoblecimiento de la ciudad al que parece rendirse con este lienzo. En el discurso histórico y político instaurado en la segunda mitad del siglo $\mathrm{XVI}$, las ciudades buscaban sus raíces y reconstruían con mayor o menor suerte su pasado histórico, de modo que no ha de extrañar el particular homenaje que El Greco dedica a la ciudad que lo había acogido, sumándose a la moda que por entonces recorría toda España. Pero, a diferencia de lo que venía siendo habitual, la tragedia de Laocoonte le permite indagar en los míticos orígenes de Toledo. Con-

17 El discurso completo esta recogido por J. BRown; op, cit. Por su parte David DAVIES mantiene la afinidad de Domenikos con los círculos de misticismo. Hace una puesta al día en el catálogo dedicando al pintor. D. DAVIES y J. ElLiot (Coords). El Greco, Nacional Gallery Company, Londres, 2003. 
vertirla en Troya supuso un alarde más de su erudición, no exenta de cierta propaganda afín a la dinastía habsbúrgica que reivindicaba a Eneas como fundador de su linaje. No es de extrañar que, inserto en esta mítica, El Greco confirme que los descendientes de aquellos valerosos troyanos fueran los fundadores de la ciudad castellana. Así pues, a medio camino entre la metáfora y la realidad, la leyenda de los héroes troyanos le sirve a Doménikos para su particular homenaje, desterrando a Hércules, pese a que era la figura tradicional de los cronicones de la época que lo tenían por protagonista indiscutible.

Como suele ocurrir, la metamorfosis operada por El Greco, aunque plenamente original hasta ahora en la pintura, podría ser fruto de la permeabilidad que la espiritualidad y la propaganda cívica imprimían en la vida. Uno de los predicadores más distinguidos del momento, fray Bernardo de Piña ya asociaba la legendaria Troya con Toledo y así avisaba de males futuros que avanzan imparables directos al corazón de la urbe ${ }^{18}$. Hacia ella se dirige el caballo, enigmático y ajeno al drama del primer plano, y en ese caminar se han querido ver un sinfín de significados. Desde la paulatina decadencia que se cierne en el horizonte, a la sinrazón dogmática de los nuevos tiempos ahogando las voces de hombres ilustres.

El mismo virtuosismo e intenciones similares las encontramos en Vista y plano de Toledo, pintada en los mismos años, de 1608 a 1614 y para D. Pedro Salazar y Mendoza, administrador del hospital de Tavera, coleccionista de mapas y vistas de ciudades. A su muerte, acaecida en 1629 , el inventario de sus bienes cita «un cuadro con la ciudad de Toledo con su planta» (Fig. 8).

A diferencia de otros paisajes en los que ha hecho gala de un absoluto subjetivismo, en el Plano y vista de Toledo desarrolla su visión más objetiva, realzada por el propio plano de la ciudad que sostiene el joven de la izquierda, lo que no le impide introducir algunas licencias y caprichos. La dualidad de lenguajes permanente en El Greco, y especialmente al final de su vida, hace que para unos esta sea una composición caracterizada por la «exactitud topográfica», mientras que para otros más que una «vista», sea un paisaje imaginario, ideal y emblemático. La clave esta en esas licencias que introduce. Especialmente dos; por un lado la figura revestida de oro y sosteniendo un cántaro y una cornucopia de la que fluyen todo tipo de riquezas y alimentos. Es una alusión culta al Tajo, siguiendo las pautas del Helenismo que ya había hecho del Nilo un anciano que trae la abundancia y prosperidad a las tierras que baña. En esta ocasión, El Greco usa todo el repertorio de los emblemas que los humanistas de la ciudad despliegan en las arquitecturas efímeras y entradas triunfales que tienen lugar en Toledo.

18 Los sermones de fray Bernardo de Piña son tratados por Fernando MARTínEZ GIL en el texto antes citado, a quien desde aquí agradezco las sugerencias que su lectura me ha proporcionado. 


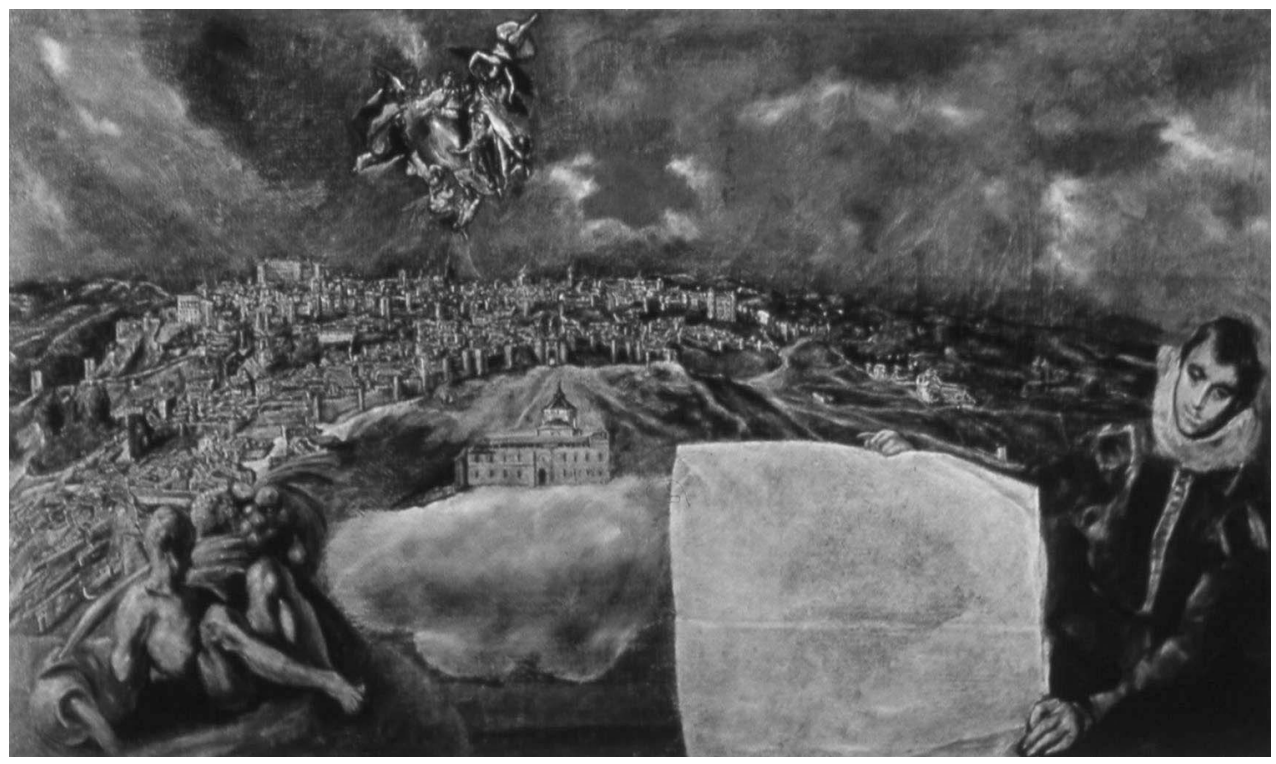

Fig. 8. Plano y vista de Toledo. Toledo, Museo de El Greco.

Otra de las licencias es la alusión al milagro de la Descensión de la Virgen para imponer la casulla a su gran defensor, San Ildefonso, patrón de la diócesis toledana con lo que rinde culto a la poderosa sede primada de España. Finalmente, el edificio que a manera de maqueta dispone sobre una nube es una clara señal de su cliente, a quien honra de este modo. En efecto, la ubicación del hospital Tavera y la primacía que adquiere es una cortesía hacia D. Pedro Salazar de Mendoza, administrador de la institución y que ya le había encargado años antes la decoración de toda la iglesia. Para su ejecución, el Greco cuenta con las «veduttas» que él ha conocido en Venecia, pues la tradición veneciana por la topografía no le es desconocida ${ }^{19}$. De hecho, el historiador Juan Manuel Cossío llegó a decir que en el Plano y vista de Toledo Doménikos había hecho «...Un Toledo como las Venecias del siglo XV, con cigarrales y vega sustituyendo a las lagunas, y la casulla de San IIdefonso... en vez del león de San Marcos» ${ }^{20}$.

La inscripción que acompaña el plano aclara algunos de los puntos más oscuros en su comprensión pero también ha dado pie a todo tipo de interpretaciones.

19 En efecto, una de las primeras noticias que se tienen de El Greco nada más llegar a Venecia es el envío a Creta de unos mapas cartográficos que le habían sido pagados. Por eso en algún momento se le vinculó con la elaboración de esta disciplina que le sería conocida a través de un precedente como era la Vista de Venecia de Jacopo de Barbari.

20 Se trata de un original paralelismo de J. M. Cossío en El Greco, Espasa Calpe, Madrid, 1984. 
Para algunos es una declaración de sus principios estéticos. Para otros, un reflejo de sus tendencias antinaturalistas en una época donde triunfa ya el naturalismo barroco. También hay quien lo ha entendido como muestra de las preferencias neoplatónicas, poniendo en relación sus palabras con el tratado de óptica de J. Pecham, Perspectiva comunis en el que se recoge la misma idea sobre los efectos de las luces en la lejanía ${ }^{21}$.

Aún en el caso de que no fuera El Greco quien terminara la obra, sino su hijo Jorge Manuel, el mensaje implícito sólo puede ser fruto de su genial capacidad para sintetizar ideas claves. A la manera de los cronicones y argumentando con las mismas raíces clásicas, influido por ellos o en un claro guiño de complicidad, El Greco despliega la grandeza de la ciudad, protegida por el milagro y distinguida por el Tajo destacando la nobleza que muchos le niegan al haber quedado descartada como capital de España.

En la reflexión final sería necesario cuestionar el porqué El Greco mantiene siempre un mismo encuadre de Toledo, produciendo a la larga la sensación de un paisaje-tipo que más que a un lugar real responde a una voluntad intelectual. Unas de las cuestiones que más ha llamado la atención ha sido la seriación o repetición de sus motivos pictóricos. Y es cierto que se le ha acusado de una falta de invención a la hora de solucionar compositivamente un tema, pero no es menos cierto que en el ámbito del Manierismo la «invenzione» no era el aspecto más atrayente de la pintura22.

En el caso del paisaje sucede algo similar. El pintado por El Greco siempre ofrece los mismos hitos arquitectónicos, poniendo un énfasis evidente en los edificios que definen la personalidad histórica, religiosa y política de Toledo. Lo mismo ocurre con los historiadores y cronistas que en la segunda mitad del siglo XVI, reconstruyen su pasado glorioso partiendo de unos tópicos comunes a otras ciudades como Granada o Sevilla. En este sentido, la mirada grequiana coincide con la de sus contemporáneos porque todos los grabados y estampas que difunden la imagen de la ciudad destacan especialmente esos tres elementos. La catedral como hito religioso, el alcázar como símbolo del poder político e imperial y el Tajo como dios pagano que fertiliza las tierras que baña. La facilidad de su identificación puede hacernos pensar que El Greco sigue una disciplina topográfica reproduciendo fielmente tales elementos. Pero ya se ha visto que no es así. Las li-

21 En una sugerencia desarrollada por J. BRown en op.cit.

22 En este sentido y como fruto del ambiente manierista, sólo caben dos posturas; o hablar de una «indolencia mental» por parte del pintor al afrontar la solución de la historia, o una actitud filosófica a la hora de solucionar la narración. Y dada la trayectoria intelectual, vital y artística de Doménikos sólo cabe la segunda respuesta por la cual siempre introduce pequeños giros y variantes con los que impone registros y matices nuevos a las historias Ver F. MARíAS, op. cit. (1997) 
cencias aparecen por doquier y también la «desarquitecturización» ${ }^{23}$ de los edificios, es decir, un paulatino proceso de desmaterialización del volumen arquitectónico que ayuda a crear la atmósfera alucinatoria y espectral que impregna esos fondos paisajistas.

Siendo siempre el mismo perfil de Toledo este, en cambio, se metamorfosea en las ciudades míticas del cristianismo. Toledo es Egipto, es Jerusalén, es el Gólgota y el Jordán, pero también adopta la apariencia de la campiña italiana que todavía retiene en su recuerdo y, si es necesario, Toledo es la vecina ciudad francesa de Tours. Esta capacidad de transformación no deja de ser una novedad iconográfica que El Greco supo explotar convenientemente según quienes fueran sus clientes. Por eso, rindiendo un tributo al círculo de humanistas, eruditos e intelectuales que le acogió, les brinda Troya bajo la apariencia de una Toledo revestida del lenguaje propio del Renacimiento más culto y elitista.

A pesar de ser imágenes impregnadas de la más absoluta ambigüedad y enigma, es posible que en la inagotable capacidad camaleónica con la que El Greco mira a Toledo no haya también un cierto desdén hacia las posiciones más reivindicativas que reclamaban el lugar de Toledo como ciudad imperial. Es posible, también, que sólo fuera una buena fórmula, filosófica y moral, con la que satisfacer el capricho de una clientela aficionada a la cultura clásica y que gustaba de las licencias poéticas habituales en la producción del cretense.

${ }^{23}$ Término empleado por F. MARÍAs en Las ideas artísticas... op. cit. 